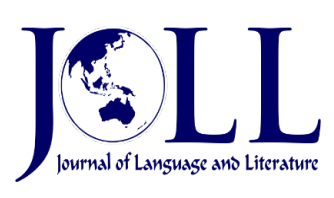

Vol. 21 No. 1, April 2021, pp. 148 - 159

DOI: 10.24071/joll.v21i1.3000

Available at https://e-journal.usd.ac.id/index.php/JOLL/index

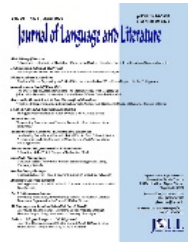

This work is licensed under a Creative Commons Attribution-ShareAlike 4.0 International License.

\title{
Kartini and Srikandi: Representation of Women in Indonesian Political Discourse through Metonymy
}

\author{
Muhammad Adam, Siti Hafsah \& Wahyuni \\ adam@uniba-bpn.ac.id, siti.hafsah@uniba-bpn.ac.id,wahyuni@uniba-bpn.ac.id \\ Faculty of Letters, Universitas Balikpapan, INDONESIA
}

\begin{abstract}
The representation of women in politics is one of the most discussed topics in Indonesian political discourse, including political discourse in media, particularly in the Indonesian context. Two metonymies are commonly used to refer to women politicians in the Indonesian context, the first is Srikandi and the second is Kartini, both are well-known figures in Indonesian history and culture. This paper discusses the use of those two metonymies to speak about women politicians in Indonesian political discourse. The focus of the investigation is the extent of the use of the metonymy across political parties and Indonesian political level, from national to local, and the influence of the context of time to the metonymy chosen in a particular discourse. The study will also examine the characteristics that are associated with the two figures that are highlighted in metonymic use. The study is descriptive qualitative with Conceptual Metaphor Theory - CMT as the theoretical background with ten data from news headlines that are purposively chosen for this study. The result shows that the metonymic use of both figures is extensive across parties and political levels. It is also found that the context plays important role in the use of Kartini particularly during the celebration of Kartini day on April 21; Whereas the notions of women empowerment are not reflected from all metonymic use. Thus, the text producers should not only use Kartini and Srikandi as metonymy just because of gender relatedness but should reflect more on women empowerment.
\end{abstract}

Article information

Keywords: Metonymy; Political Discourse; Srikandi and Kartini;, Women in Politics.

\section{Introduction}

Politics is one of the modern fields in which women initially struggle to gain position and to gain equality. Lovenduski, Campbell, \& Sampson-Jacent (2002) assert there are three reasons for the low participation of women in politics and parliament, i.e: structural impediments, political institution, and political culture. In Indonesia, there has been a regulation for an electoral quota for women's representation in 
the legislative institution. Indonesian Law number 7 the year 2017 regarding the general election has set that the political party must ensure that at least 30 percent of the candidates in the level of the constituency are women. Anggraini (2020) agrees that women's representation in parliament has shown an improvement, where during the Indonesian election 2019, resulted in the highest women politician elected as members of the Indonesian House of Representatives. 120 female candidates are successfully elected from a total of 575 seats which equals $20,87 \%$.

Few studies focus on political communication regarding the image of women politician, one of them is by Yuniati \& Fardiah (2017) who study the image of female legislative candidates in media online framing and reports one of them that women legislative candidates can become parliament members in terms of complying the factors of knowledge and education, spiritualism, economy and public roles in politics. Nevertheless, not many studies focus on the metonymic use describing women politicians. This study attempts to look at that dimension, by examining the use of metonymy in describing women politicians. Furthermore, the study of metonymy in the Indonesian political context still receives less attention compare to metaphor although the use of metonymy is common.

Littlemore (2015) defines metonymy as "a figure of language and thought in which one entity is used to refer to or in cognitive linguistic terms 'provide access to' another entity to which it is somehow related".(p.4). One of the types of word commonly used as metonymy is a proper name to refer to a particular entity. Specific characteristics and traits from a particular person -and becomes general knowledge- will make it possible to use as metonymy, in one condition, that another person or entity to be described shall have the similarity of the characteristic or trait.

In Indonesian media discourse, Srikandi and Kartini are commonly used to refer to women who have a significant role in the field that is (culturally) associated with men's world. This study aims to highlight the elements transfer or mapping of the metonymic use of both figures in Indonesian political discourse across the political level since the pervasive metonymic use in Indonesian political discourse raises the question of whether or not women empowerment is fairly reflected during metonymic use.

An example below:

Example 1:

Prestasi Sri Mulyani, Srikandi Jokowi di Bidang Keuangan (CNN Indonesia, 2019)

Sri Mulyani's Achievement, Jokowi's

Srikandi in Financial field.

The use of Srikandi in example 1 above refers to Sri Mulyani who is the current minister of finance. Her achievement and expertise in the financial field have made the media compare her to Srikandi in the field. By understanding both concepts and figures, Srikandi and Sri Mulyani, the metonymy interpreter shall arrive at the correct interpretation.

A similar metonymic model in the next example, the use of Kartini in Indonesian media and read by Indonesian readers, shall be interpreted effortlessly. Since readers have a historical and cultural knowledge of Kartini.

Example 2:

"Kisah Dua Kartini Teknologi di Balik Suksesnya Startup Unicorn" (Utama \& Berlian, 2020)

The story of two tech Kartinis behind the success of Unicorn Startup.

The metonymic use of Kartini in example 2 above is to describe two women who have been successful in their career in building an internet start-up industry. The relatedness is not only on the same gender between Kartini and the two successful women but also the equality in the industry. Readers' knowledge of Kartini is very important to gain full interpretation intended. 
From example 1 and example 2 above, the characteristic that enables Srikandi and Kartini to be used as metonymy is not only the similarity on gender but also the ability to compete and to show gender equality. Srikandi and (particularly) Kartini are the symbolism of women's equality in various aspects and are commonly used in discourse.

The birth of CMT (Lakoff and Johnson, 1980) has brought a new dimension in the study of metaphor and metonymy. CMT promotes the view that metaphor is not only at the linguistics level, but lies on our conceptual or cognitive level. They agree that Metonymic concepts are systematic in the same way that metaphoric concepts are and assert that same with metaphor, metonymy is part of our everyday way of thinking, is grounded in our experience, is subject to general and systematic principles, and structures our thoughts and actions. In their view, metonymy is not only primarily a referential function, but it also contributes to understanding.

If metaphor is the cross-domain mapping, metonymy is the same domain or asymmetric mapping as asserted by Barcelona (2004) who agrees that metonymy is a conceptual projection or mapping in a single, asymmetric mapping, with no counterpart matching. This view is also supported by Radden \& Kovecses (2007) and use the terms Idealized Cognitive Models (ICM) as the alternative terms for frame and image schema. They assert that "Metonymy is a cognitive process in which one conceptual entity, the vehicle, provides mental access to another conceptual entity, the target, within the same idealized cognitive mode".

Socio-cultural knowledge is very important in understanding the hidden meaning behind a particular metonymy. Zinken, Hellsten, \& Nerlich (2008) assert that in discourse metaphors, knowledge associated with basic level categories is projected onto the target domain; and the conventionalization of a particular projection into a discourse practice is a socio-cultural process. We believe that metonymy operates in the same way. Thus, In the Indonesian context, the use of Kartini and Srikandi is related to the conventionalization of a projection from the two entities spoken in discourse with the same characteristics and is based on shared socio-cultural knowledge.

There are several metonymy types, one of them is by Lakoff and Johnson (1980) who provide the metonymy models, some of them are: PART FOR WHOLE (e.g. We need a strong hand for this job); PRODUCER FOR PRODUCT (e.g He drives a Honda); CONTROLLER FOR CONTROLLED (Washington asks Beijing for permission to send health team to the battle outbreak); PLACE FOR INSTITUTION (White house asks US employers to strengthen the economy), etc. Whereas Radden \& Kovecses (1999) provide a broader taxonomy of the key metonymy types which is then added by Littlemore \& Tagg (2016) who provide each example of a creative metaphor used in text messages. Whereas, Adam (2018) who studies the metonymic use of Bill Gates reports that the richest man, the philanthropist, the successful drop-out college are some of the characteristics of Bill Gates that are transferred in a particular discourse on its metonymic use.

This study aims to investigate the use of those two main Indonesian woman figures, i.e: Srikandi and Kartini as metonymy to refer to women politicians in Indonesian political discourse. The focus of the investigation is the extent of the use of the metonymy across political parties and across the Indonesian political level, and the influence of the context of time on the metonymy chosen in a particular discourse. The study will also examine the characteristics of the figures that are highlighted in metonymic use

\section{Methodology}

Ten news headlines are purposively chosen in this study. The headlines all contain the metonymic use of Kartini and Srikandi in the political context. This study approaches the metonymy within the framework of Conceptual Metaphor Theory (CMT) of Lakoff and Johnson (1980). CMT framework is used, as this study relates the metonymy and the entity it represents within the cognitive framework, and with the conceptual mapping, to which CMT provides the theoretical ground which further formulated in detail by Radden 
and Kovecses (2007) on the cognitive view of metonymy.

During analysis and interpretation, the characteristics of the element mapping are conducted to examine what elements from the traits of the figures are potentially mapped onto the target domain. As metaphor and metonymy operate similarly on the concept of elements transfer principle, Thus, the mapping analysis is adopted from Ahrens', (2014) work on mapping principle for conceptual metaphor.

The results and discussion will be presented based on four aspects. The first is the extent of the metonymic use of Srikandi and Kartini across parties and political level, the second is the effect of context on the use of both metonymies, and the third is the use and combination with other metonymy and the fourth is the discussion of the highlighted elements to measure whether or not the metonymic use of Kartini and Srikandi implied the characteristics or traits that show a significant notion of women empowerment. Throughout this paper, the metaphor producer and metaphor interpreter will be frequently used. The first refers to journalists who use metonymy in the news report; the latter refers to reader or audience in general

\section{Results and Discussion}

In the Indonesian context, the metonymic use of Srikandi and Kartini in discourse is commonly used to refer to the women that play a significant role in the modern profession. It follows the type or the ICM PERSON FOR TRAIT, this ICM has also been affirmed by Littlemore (Personal Communication, July 6, 2020). PERSON FOR TRAIT is an ICM where a name of a person is used as metonymy because of its unique characteristics that is assumed known in general. It means that the characteristics of Srikandi and Kartini, which is culturally and historically understood by Indonesian people, enable those two to be used as metonymy for women in their professional settings. Srikandi and Kartini as metonymy is not only used in the political context, but also across fields and in everyday discourse
Dewi Wara Srikandi is a woman figure in Javanese shadow puppet theatre (wayang kulit) story and is famously known as Srikandi (Azizah \& Wirawanda, 2019) who has military prowess and masculinity characters. Solichin (2016) asserts that Srikandi has the characteristics of a strong goddess, high skill in archery, and a woman heroine in Javanese wayang story that make Srikandi is used as a symbol of women achievement and equality.

As for the Kartini, her full name is Raden Adjeng Kartini, born in 1879, was a Javanese aristocrat who became a fierce proponent for gender equality and education. Asmarani (2013) asserts Kartini, a champion of women's emancipation in the Dutch colonial time where most of her thought was reflected from her letters, Yulius (2016) affirms that different from the modern feminist notion, Kartini emphasized the empowerment of Indonesian women could not be separated from the role of mother and wife. In one letter, Kartini highlighted the importance of women and motherhood. "It is from women that humans receive their first education on a woman's lap, a child gradually learns to feel, think and speak; I came to realize more and more that the effect of the first education is not insignificant to human life ..." (in Yulius, 2016). Woodward (2015) describes Kartini as "an Indonesian national heroine, considered Indonesia's founding feminist" (p.5).

In the educational field, Kartini's view and principle are also becoming the focus of study by Mulatsih \& Putri (2020) and assert that Kartini's teacher concept and principle put moral and intellectual aspects as essential aspects in teaching. Thus, Kartini's views and principles on women empowerment have been historically and socio-culturally embedded in Indonesian people, and are commonly used in various discourses as a metonymy to evoke women's emancipation and is not limited only in the political sphere, but also across discourses. Every April 21 $1^{\text {st }}$ is commemorated as Kartini day and reflects women's emancipation in all fields.

Each of the two figures has different highlighted characteristics on women empowerment. Srikandi's traits are of mastering men's skills, patriotism, and 
independence, whereas Kartini reflects the combination of women empowerment with still maintaining the role of motherhood.
The data collected for the metonymic use of Srikandi and Kartini are presented in Table 1 below:

Table 1. The Metonymic Use of Srikandi and Kartini in News Headlines

\begin{tabular}{|c|c|}
\hline $\begin{array}{l}\text { Data } \\
\text { Code }\end{array}$ & Headlines \\
\hline \multirow{2}{*}{1} & $\begin{array}{l}\text { Srikandi 'Banteng' Salurkan Bantuan Lawan Covid 19, Pasok Sembako Pakai Ojol (Noor, } \\
\text { 2020) }\end{array}$ \\
\hline & $\begin{array}{l}\text { Srikandi of "Bulls" distribute aid to fight against Covid-19, supplying to online taxi } \\
\text { rider". (Noor, 2020) }\end{array}$ \\
\hline \multirow[t]{2}{*}{2} & $\begin{array}{l}\text { Sri Laelasari, Srikandi Gerindra yang Siap Perjuangkan Nasib Emak-emak (Kumparan, } \\
\text { 2019) }\end{array}$ \\
\hline & Sri Laelasari, Srikandi of Gerindra who is ready to fight the women's nasib. \\
\hline \multirow{2}{*}{3} & $\begin{array}{l}\text { Golkar Selektif, Satu Dari Tiga Srikandi Beringin Tomohon Bakal Gigit Jari (Marentek, } \\
\text { 2020) }\end{array}$ \\
\hline & $\begin{array}{l}\text { Golkar party is selective, one out of three Srikandi of Beringin Tomohon will (lit.) bite } \\
\text { fingers. }\end{array}$ \\
\hline \multirow{2}{*}{4} & Devita Rusdy Ajak Srikandi Partai Demokrat Bagikan Sembako.(Fikri, 2020) \\
\hline & Devita Rusdy urges Srikandi of Demokrat Party to distribute basic food packages. \\
\hline \multirow[t]{2}{*}{5} & $\begin{array}{l}\text { Srikandi NasDem Tabanan Sumbang Paket Internet Bantu Siswa Belajar di 'Rumah } \\
\text { Aja'.(Bali, 2020) }\end{array}$ \\
\hline & Srikandi of Nasdem donate Internet package to help students study from home. \\
\hline \multirow{2}{*}{6} & $\begin{array}{l}\text { Peringati Hari Kartini, } \text { Srikandi Golkar } \text { Manggarai } \\
\text { Vitamin.(Floresa, 2020) }\end{array}$ \\
\hline & $\begin{array}{l}\text { Commemorate Kartini day, The Srikandi of Golkar Manggarai distribute masks and } \\
\text { Vitamin. }\end{array}$ \\
\hline \multirow{2}{*}{7} & Lilik Hendarwati, 'Kartini' yang Berani Terjun ke Dunia Politik.(Ramzi, 2016) \\
\hline & Lilik Hendarwati, The Kartini who dares to jump into politics. \\
\hline \multirow{2}{*}{8} & $\begin{array}{l}\text { Jelang Ramadhan, Kartini Golkar Bagikan Ratusan Sembako dan Ribuan Masker.(Fuad, } \\
\text { 2020) }\end{array}$ \\
\hline & $\begin{array}{l}\text { Approaching Ramadhan, Kartini of Golkar distribute hundreds of basic food packages } \\
\text { and thousands of masks. }\end{array}$ \\
\hline \multirow{2}{*}{9} & $\begin{array}{l}\text { Tiga "Kartini" Golkar Tanjungbalai diperkirakan terpilih jadi anggota DPRD. (Antara, } \\
\text { 2019) }\end{array}$ \\
\hline & $\begin{array}{l}\text { Three Kartini of Golkar Tanjungbalai are predicted to be elected as member of house of } \\
\text { Representatives. }\end{array}$ \\
\hline \multirow{2}{*}{10} & $\begin{array}{l}\text { Aktif di Politik dan Sosial, Kartini 'Senayan' Ini Gigih Perjuangkan Nasib Perempuan. } \\
\text { (Tribun, 2020) }\end{array}$ \\
\hline & $\begin{array}{l}\text { Being politically and socially active, This Kartini of Senayan is determined to fight for } \\
\text { women. }\end{array}$ \\
\hline
\end{tabular}

Four aspects become the point of discussion from the finding. The first is the metonymic usage across parties and political level, the second is the role of context of the 
time in the metonymy chosen, the third is the combination with other metonymies that add more political sphere and the last is the highlighted characteristics mapping.

\section{Metonymy across Parties and Political Level}

Metonymic use of Kartini and Srikandi as metonymy in Indonesian media particularly that refer to women politicians is widely found to refer to all parties and all political level. Across parties, there are six parties in data code that use the metonymy as seen from data code 1 till data code 9 that uses the metonymy to refer to the member of different political parties. It shows that the extent of the use does not limit based on political parties' platform and ideology, but also across the parliamentary level, the national level and the regional level are also found. In The national level the use of both metonymies is also found as well as in the provincial and city or regency political level as seen in data code 10 (national), and data code 3, 6, and 9 (Provincial and city/regency level)

\section{Data Code 10}

Aktif di Politik dan Sosial, Kartini Senayan' Ini Gigih Perjuangkan Nasib Perempuan Being politically and socially active, This Kartini of Senayan is determined to fight for women.

The use of Kartini "senayan" above shows the national level of political stage.

Whereas in data code 3 , data code 6 , and data code 9 below, consecutively describe the regional and local political level of Tomohon, Manggarai, and Tanjung Balai.

\section{Data Code 3}

Golkar Selektif, Satu Dari Tiga Srikandi Beringin Tomohon Bakal Gigit Jari Golkar party is selective, one out of three Srikandi of Beringin Tomohon will (lit.) bite fingers

Data code 6
Peringati Hari Kartini, Srikandi Golkar Manggarai Bagi-bagi Masker dan Vitamin Commemorating Kartini day, The Srikandi of Golkar Manggarai distribute masks and Vitamin

Data code 9

Tiga "Kartini" Golkar Tanjungbalai diperkirakan terpilih jadi anggota DPRD. Three Kartini(s) of Golkar Tanjungbalai are predicted to be elected as a member of the regional house of Representatives.

The cross-parties and cross-region and places of metonymic use of Srikandi and Kartini reflect the pervasiveness and the commonality of the use in representing women politician.

\section{Metonymic Use based on context}

The examination of the use of metonymy shows that Srikandi is used more frequently than Kartini. The use of Srikandi is not significantly affected by the context of which month the news report is, whereas when the news report is in April, particularly approaching April 21, Kartini is used more frequently. Kovecses (2014) agrees with the role of contextual factors in metaphor on particular occasions and range from global to local along the physical, social, cultural, historical, linguistic, dimensions. The metaphors used in discourse are selected in conformity to them. It is the same case with metonymy.

We find that the metonymic use of Kartini is chosen because the context is closed with the celebration of Kartini Day. Data code 7, data code 8 , data code 9 , and data code 10 are used as a headline in news reports consecutively on April 21, April 21, April 22, and April 20.

Whereas in data code 6 below, although the headlines were used on April 21, but Srikandi is still used as metonymy. The summary of the comparison between date and the metonymic use is presented in table 2 below. 
Table 2. Date of News Publication

\begin{tabular}{|c|l|l|}
\hline Data Code & \multicolumn{1}{|c|}{ Metonymy } & \multicolumn{1}{c|}{$\begin{array}{c}\text { Date of News } \\
\text { Report }\end{array}$} \\
\hline 1 & Srikandi Banteng & 06 April \\
\hline 2 & Srikandi Gerindra & 13 September \\
\hline 3 & Srikandi Beringin & 07 June \\
\hline 4 & Srikandi Partai Demokrat & 05 April \\
\hline 5 & Srikandi Nasdem & 18 April \\
\hline 6 & Srikandi Golkar & 21 April \\
\hline 7 & Kartini & 21 April \\
\hline 8 & Kartini Golkar & 21 April \\
\hline 9 & Kartini Golkar & 22 April \\
\hline 10 & Kartini Senayan & 20 April \\
\hline
\end{tabular}

It shows that the choice of the particular metonymy used is also affected by the context of time. If there are two metonymies options for a particular characteristic, the one that closest much with the context of time will be chosen.

Also, culturally Srikandi implies traits associated with men's world as asserted by Sholikhah \& Masruroh (2019) who summarize Some of the values of Srikandi feminism that can be applied as character education for gender equality,i.e: Mastering skills that associated with men's skill such as military, archery, war, and being a leader are very identical to men; Ability to defend the country; Ability to perform multiple roles and; being independent and actively learning.

\section{The combination with other metonymies}

The persuasive effect of metonymy in political discourse will even stronger if it is combined with another metonymy that also brings particular political characteristics as asserted by Pérez-Sobrino, Littlemore, \& Houghton (2019) that "complex figurative operations were perceived as more appealing" (p. 30). It can be seen from the metonymic use of Kartini and Srikandi, where they are used with another political metonymy as seen in data code 1 below:

\section{Data Code 1}

\section{Srikandi 'Banteng' Salurkan Bantuan Lawan Covid 19, Pasok Sembako Pakai Ojol}

(Srikandi of "Bulls" distribute aid to fight against Covid-19, supplying basic food package to online taxi rider")

Srikandi 'banteng' (bulls), refer to the women members of the PDI-P political party, which uses banteng (bulls) as the party symbol. The universal and also cultural view of banteng adds an extra persuasive sphere to the metonymy and stresses the political aspect of discourse. Apart from the symbolic representation of the bulls as the political party, the embedded entailments of bulls infer strong and powerful characteristics. This brings an extra implication to the discourse and along with the metonymic usage of Srikandi.

Same with data code 1 above, in data code 3 below, Srikandi is directly followed by "beringin" (banyan tree) a type of tree that becomes the symbol of political party Golkar. Banyan tree itself in some cultures across Indonesia signifies a particular symbol; one of them is asserted by Ali (2019) who studies the ornament of the traditional house of Gorontalo and finds that one of the ornament is the banyan tree ceiling that symbolizes strength and unity. Therefore, for the 
interpreter, reading the metonymic of Srikandi and followed by the banyan tree will unconsciously trigger other additional inferences and image schema.

\section{Data Code 3}

"Golkar Selektif, Satu Dari Tiga Srikandi Beringin Tomohon Bakal Gigit Jari". Golkar party is selective, one out of three Srikandi of Beringin Tomohon will (lit.) bite fingers

Also, an additional metaphor "gigit jari" is used. Gigit jari (literally bit finger) is a gesture when one does not receive what one wants, and is used and metaphorically to describe the disappointment. In the particular context of data code 3 , the disappointment refers to the selection of the legislative candidates, that out of three women politicians that are metonymically described as Three Srikandis, only one will be appointed by their party.

The metonymic use of Srikandi in data code 3 above asserts that all of the legislative candidates are women.

In data code 10, the metonymic use of Kartini is combined with another famous Indonesian metonymy of political discourse, i.e: "Senayan", a common metonymy for the House of Representatives. Senayan is literally a name of a place in Jakarta where the building of the House of Representatives is located. Its use is similar to "Capitol" in United States political discourse.

The use of the place name in the Indonesian political context is also pervasive. Adam (2019) reports how "Cendana", the address of the Indonesian second president is used as the metonymy for the second president's family and relative in media discourse.

The additional place name metonymy of Senayan triggers a stronger political sphere to the discourse, as the metonymic itself is widely used and widely known as the center of the Indonesian political field, particularly on the legislative side.
Data code 10

"Aktif di Politik dan Sosial, Kartini 'Senayan' Ini Gigih Perjuangkan Nasib Perempuan".

Being politically and socially active, This Kartini of Senayan is determined to fight for women.

As seen from data code 1 , data code 3 , and data code 10 , each has a combination with other metonymies that can reinforce the political sphere, from the metonymy of the political party symbol, until the place name metonymy that is associated with Indonesian political center.

\section{The Highlighted elements of Srikandi and Kartini in Metonymy}

Gender relatedness should not the only aspect to highlight in using Kartini and Srikandi as metonymy, but it should also evoke particular characteristics that are related to women empowerment. Kartini for instance shall evoke more political sphere as the context in which she spent her life was mostly during the political movement during the colonialization period and fighting not only for gender equality but also as a person from a colonized country.

The creative use of metonymy enables the metonymy producer to highlight a particular characteristic of the metonymy used. Littlemore (2015) agrees that metonymy can highlight a given phenomenon while downplaying others that enable it to either consciously or unconsciously to present a metaphor producer perspective. The ICM Person for traits or characteristics in the metonymic usage of Kartini and Srikandi has shown that not all metonymy uses the same highlighted characteristics of the women empowerment or gender equality traits.

The highlighted characteristics that are implied from some of the data do not show optimum mapping of women empowerment characteristics from two woman figures used as metonymy, particularly Kartini. Instead, some data shows that the traits from Kartini that is transferred during the metonymic use lie heavily on the gender similarity. 
The ideal traits and characteristics of Kartini should be one of them reflecting her struggle for gender equality. The comparison of how fewer traits of Kartini are reflected from the metonymic use can be seen from data code 8 .

Data Code 8:

"Jelang Ramadhan, Kartini Golkar Bagikan Ratusan Sembako dan Ribuan Masker". Approaching Ramadhan, Kartini of Golkar distribute hundreds of basic food packages and thousands of masks.
The discourse in data code 8 above does not suggest any significance on the activity of distributing the basic food packages and masks as an extraordinary characteristic,

Figure 1 below shows that there are only two traits that can be mapped from Kartini's traits to the target; they are gender relatedness and taking the role in the political field. Whereas other significant aspects of Kartini's traits such as fighting for women empowerment, politically and culturally struggle are missing from contexts.

Figure 1. The Mapping of Characterictics of Data code 8

\section{KARTINI - Implied Traits and Characteristics}

\section{KARTINI IN DATA CODE 8}

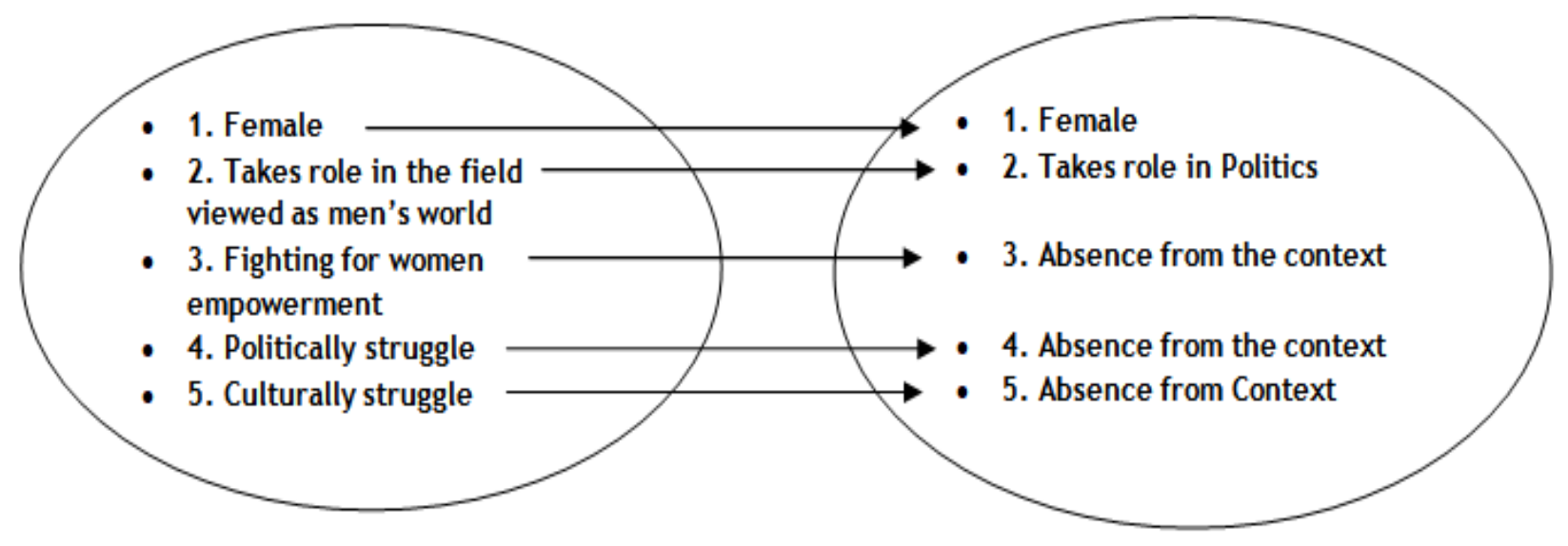

The creative use of metonymy as one of the persuasive tools in media discourse should also pay more attention to whether or not the criteria of the target to use a particular proper name as metonymy can be applied. Otherwise, it may deduct the value of the initial traits and characteristics embedded in the figures used as metonymy as seen in the finding described in figure 1 above, that there are more elements of characteristics of Srikandi figure that are not mapped onto the metonymic use.

Whereas in data code 10 below, there are more traits and characteristics of Kartini and even the women empowerment and political sphere that are reflected from the use of Kartini as metonymy.
The use of place-name metonymy "Senayan" has significantly added the political sphere to the use of metonymy.

Data Code 10

\section{Aktif di Politik dan Sosial, Kartini \\ 'Senayan' Ini Gigih Perjuangkan Nasib Perempuan. \\ Being politically and socially active, This Kartini of Senayan is determined to fight for women's fate.}

In figure 2 below, the mapping of elements from the source figures of Kartini to the target figures results in a thorough transfer, not only gender relatedness, but also it implies the sphere of fighting for women empowerment, and politically and culturally struggle. 
Figure 2. The Mapping of Characteristics of Data code 10

KARTINI - Implied Traits and Characteristics

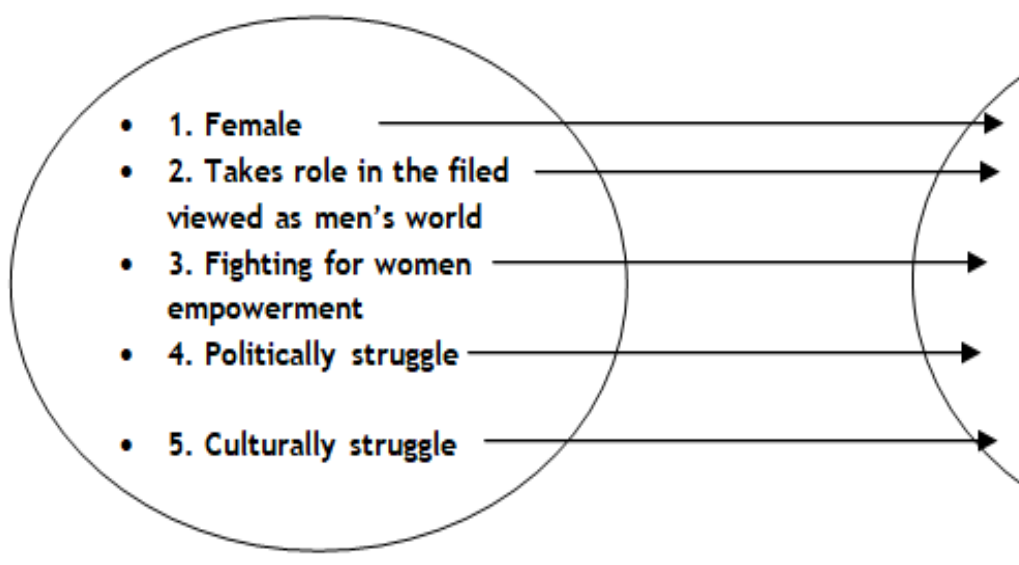

KARTINI SENAYAN IN DATA CODE 10

empowerment is important to carry more characteristics on its metonymic use. This is important so that the metonymic use shall not only highlight the gender aspects but also beyond that, it highlights the struggle or the strength. In particular with the metonymic use of Kartini, should be used also as a metonymy for how women fighting for gender equality while still maintaining the role as a mother and a wife. By embedding other political struggles in the metonymic use, it shall implicitly send messages to metonymy interpreters. Metonymic use is not only linguistic expressions, but the socio-cultural and historical aspects are very important and should also be brought forward.

The ability to interpret a metonymic use of a proper name relies heavily on the interpreters' or readers' knowledge of the metonymic source domain. In this particular case, the socio-cultural, historical, and political awareness of both Srikandi and Kartini is very important to gain a comprehensive interpretation of the usage. Otherwise, the only characteristics it carries is not far beyond the similar gender. Furthermore, since metonymy involves a cognitive process that provides a sort of "short-cut" in the discourse, the similarities between a figure used as metonymy and the target that is described become the most important point to reach the intended meaning. 
The use of Srikandi and Kartini to represent women politicians in the discourse should gradually be improved by using them more to highlight other traits and characteristics of both figures by producers (journalist). It also should be conducted simultaneously, that the interpreters shall also be induced with more knowledge about traits, characteristics, and thoughts of both figures. Metonymic use of Srikandi and Kartini can be used to unconsciously and implicitly make people aware of the gender equality and women empowerment of the two figures. Otherwise, in particular to Kartini, if it is frequently used out of the women empowerment sphere and gender equality sphere, it may decrease how people perceived her figures and what role he has in fighting for gender equality.

\section{Conclusion}

This study examines the metonymic use of Kartini and Srikandi in Indonesian political discourse. It can be seen that the use is extensive across parties and across the political level. It is also found that the context plays important role in the use of Kartini particularly during the celebration of Kartini day on April 21; whereas the notions of women empowerment are not reflected from all metonymic use.

Further study by quantitatively examining the use of both metonymies across various discourses should be conducted. Also, experimental research should be conducted to measure whether or not readers can fully understand the elements that are intended to highlight in the metonymic use, to see whether they understand that Srikandi and or Kartini is not only metonymically used because of gender similarity, but beyond that, the gender equality that is fought by those two figures should also be understood. The implication of this study to the metonymic use of both figures is the need to raise awareness to the metonymy producers on the understanding of highlighted traits of both figures that are intended to transfer. Gender relatedness alone should not the only element to transfer during metonymic use of Kartini and Srikandi, but beyond that, the metonymic use should reflect more on women empowerment and women equality.

\section{References}

Adam, M. (2018). What's In A Bill Gates- A Corpus Linguistics Study of the Metonymic Use of Proper name. Prologue, 4(1), 46-78.

Adam, M. (2019). The Referents of Cendana in Media Discourse; A Study of Metonymic Use of Place Name. Sesanti (Seminar Bahasa, Sastra, Dan Seni 2019), 432-445.

Ahrens, K. (2014). 10. Mapping principles for conceptual metaphors. 185-208. https://doi.org/10.1075/hcp.26.12ahr

Ali, A. H. (2019). Study Of Form And Meaning of Symbolic Indigenous House of Gorontalo: Case Study of Building Results Of The Reconstruction of The Bantayo Po' Boide Traditional House of Gorontalo Regency. ARTic, 4. https://doi.org/https://doi.org/10.3401 0/artic.2019.4.2457.203-214

Anggraini, T. (2020, February 26). Revisi UU Pemilu dan Penguatan Keterwakilan Perempuan. Media Indonesia.Com. Retrieved from https://mediaindonesia. com/read/detail/292439-revisi-uupemilu-dan-penguatan-keterwakilanperempuan

Asmarani, D. (2013, November). Kartini the Forgotten Nationalist. Magdalene.Co. Retrieved from https://magdalene.co/ story/kartini-the-forgotten-nationalist

Azizah, F. N., \& Wirawanda, Y. (2019). Makna Female Masculinity dalam Kostum Wayang Srikandi Red Batik Solo. Jurnal Komunikasi, 11(1), 52-69. https://doi.org/10.24912/jk.v11i1.2499

Barcelona, A. (2004). Names: A metonymic “ return ticket " in five languages. Jezikoslovlje, 1(2003), 11-41. 
CNN, I. (2019, October 22). Prestasi Sri Mulyani, Srikandi Jokowi di Bidang Keuangan. CNN Indonesia. Retrieved from https://www.cnnindonesia.com/ ekonomi/20191022102852-532441705/prestasi-sri-mulyani-srikandijokowi-di-bidang-keuangan

Kovecses, Z. (2014). Context-induced variation in metaphor. Argumentum, 10, 392-402.

Lakoff, G and Johnson, M. (1980). Metaphor We Live By. Chicago: University of Chicago Press.

Lakoff, George and Johnson, M. (1980). Metaphor We Live By. Chicago: University of Chicago Press.

Littlemore, Jeanette, \& Tagg. (2016). Metonymy and text messaging: A framework for understanding creative uses of metonymy. Applied Linguistics, 39(1).

Littlemore, Jeannette. (2015). Metonymy: Hidden shortcuts in language, thought and communication. In Metonymy: Hidden Shortcuts in Language, Thought and Communication. https://doi.org/ 10.1017/CBO9781107338814

Lovenduski, J., Campbell, R., \& SampsonJacent, J. (2002). Women, Public Life and Democracy. London: Pluto Press.

Mulatsih, M. V. E., \& Putri, B. A. (2020). Kartini's Teacher Concept and Principles in Letters of a Javanese Princess. Journal of Language and Literature, 20(2), 212. https://doi.org/10.24071/joll.v20i2.236 4

Pérez-Sobrino, P., Littlemore, J., \& Houghton, D. (2019). The Role of Figurative Complexity in the Comprehension and Appreciation of Advertisements. Applied Linguistics, 40(6), 957-991. https:// doi.org/10.1093/applin/amy039

Radden, G., \& Kovecses, Z. (1999). Towards a theory of metonymy'. In K.-U. Panther \&
G. Radden (Eds.), Metonymy in Language and Thought (pp. 17-59). Amsterdam: John Benjamins.

Radden, G., \& Kovecses, Z. (2007). TOWARDS A THEORY OF METONYMY. In V. Evans, B. Bergen, \& J. Zinken (Eds.), The Cognitive Linguistics Reader (pp. 335359). London: Equinox.

Sholikhah, N., \& Masruroh, A. (2019). The Implementation of Feminist Values in Srikandi (Woman Figure on Wayang Story): A Concept to Develop Gender Equality in Java, Indonesia. Proceeding Book 7th Asian Academic Society International Conference 2019, 510-514.

Solichin. (2016). Tokoh Wayang Terkemuka. Jakarta: CV. Dedy Jaya.

Utama, L., \& Berlian, I. (2020, April 23). Kisah Dua Kartini Teknologi di Balik Suksesnya Startup Unicorn. Viva.Co.Id. Retrieved from https://www.viva.co.id/digital/ teknopedia/1212357-kisah-dua-kartiniteknologi-di-balik-suksesnya-startupunicorn

Woodward, A. (2015). Historical Perspectives on a National Heroine: R. A . Kartini and the Politics of Memory.

Yulius, H. (2016, April 21). Kartini: Between Islam, nation-building and feminism. Jakarta Post.

Yuniati, Y., Yuniati, Y., \& Fardiah, D. (2017). Citra Caleg Perempuan dalam 'Framing' Media 'Online.' 75-86.

Zinken, J., Hellsten, I., \& Nerlich, B. (2008). Discourse metaphors. Body, Language and Mind, 2, 363-386. https://doi.org/ 10.1515/COG.2007.024 